\title{
PENGARUH PEMBELAJARAN KOOPERATIF MODEL THINK PAIR SHARE (TPS) TERHADAP HASIL BELAJAR GEOGRAFI
}

\author{
Tuti Mutia*, Sri Agustina, Suroso, Ramli Akhmad \\ Program Studi Pendidikan Geografi, Fakultas Ilmu Sosial dan Ekonomi, Universitas Hamzanwadi, Selong, Indonesia \\ *Email Koresponden: mutiatia92@yahoo.co.id \\ Diterima: 04-12-2020, Revisi: 18-12-2020, Disetujui: 19-12-2020 \\ C2020 Program Studi Pendidikan Geografi, FISE, Universitas Hamzanwadi
}

\begin{abstract}
Abstrak. Tujuan pembelajaran tercapai apabila siswa secara aktif berinteraksi dengan komponen pembelajaran yang diatur oleh guru. Salah satu komponen pembelajaran yang dapat menunjang pencapaian tujuan pembelajaran adalah model pembelajaran. Salah satu model pembelajaran yang dapat menghasilkan interaksi terbuka antar siswa yaitu Think Pair Share (TPS). Model tersebut memberikan siswa kesempatan untuk berfikir dan membantu dengan teman. Tujuan penelitian ini untuk mengetahui pengaruh model pembelajaran TPS terhadap hasil belajar Geografi. Jenis Penelitian ini yaitu eksperimen semu (Quasi Eksperiment), dengan desain nonquivalent control group design. Variabel penelitian terdiri dari: 1) variabel terikat adalah hasil belajar siswa dan 2) variabel bebas adalah model pembelajarn TPS. Hasil belajar siswa diukur menggunakan tes yang terdiri dari dua yaitu tes objektif dan subjektif, Instrumen yang digunakan yaitu tes pilihan ganda yang berjumlah 40 butir. Analisis data menggunakan uji $\mathrm{T}$ independent dengan bantuan SPSS 20.00 for Windows. Hasil penelitian menunjukkan bahwa model pembelajaran TPS berpengaruh terhadap hasil belajar. TPS memberikan kesempatan kepada siswa mengembangkan kemampuan analisis terhadap suatu permasalahan dan mengkomunikasikannya.
\end{abstract}

Kata kunci: pembelajaran kooperatif, model think pair share, dan hasil belajar

\begin{abstract}
Learning objectives are achieved when students actively interact with the learning components arranged by the teacher. One of the learning components that can support the achievement of learning objectives is the learning model. One learning model that can produce open interaction between students is Think Pair Share (TPS). This model gives students the opportunity to think and help with friends. The purpose of this study was to determine the effect of the TPS learning model on learning outcomes of Geography. This type of research is a quasi-experimental (Quasi Experiment), with a nonquivalent control group design. The research variables consisted of: 1) the dependent variable was student learning outcomes and 2) the independent variable was the TPS learning model. Student learning outcomes are measured using a test consisting of two, namely objective and subjective tests. The instrument used is a multiple choice test, amounting to 40 items. Data analysis used independent T test with SPSS 20.00 for Windows. The results showed that the TPS learning model had an effect on learning outcomes. TPS provides an opportunity for students to develop their analytical skills on a problem and communicate it.
\end{abstract}

Keywords: cooperative learning, think pair share model, and learning outcomes

\section{PENDAHULUAN}

Pembelajaran kooperatif adalah suatu model pembelajaran dimana sistem belajar dan bekerja dalam kelompok-kelompok kecil yang berjumlah 4-6 orang secara kolaboratif sehingga dapat merangsang lebih bergairah dalam belajar (Slavin, 2010). Melalui pembelajaran kooperatif, kondisi belajar dapat dimaksimalkan untuk mencapai tujuan belajar (Sulfemi, 2019). Adapun komposisi atau struktur kelompok dalam pembelajaran kooperatif memiliki karakteristik dengan sifat heterogen atau beragam (Rusman dalam Wijaya \& Arismunandar, 2018). Heterogenitas tersebut juga mencakup tingkat kemampuan akademik peserta didik. Proses pembelajaran dengan pembelajaran kooperatif mendorong siswa aktif dan berpartisipasi dalam kelompok sehingga dapat meningkatkan hasil belajar mereka. Hal 
ini sesuai dengan keuntungan pembelajaran kooperatif bagi siswa yaitu mereka akan lebih mudah memahami materi pembelajaran jika mereka berdiskusi kelompok (Slavin, 2010).

Keuntungan lain dari pembelajaran kooperatif menurut Lundgren (dalam Lamba, 2016) adalah siswa mampu mengingat materi pelajaran lebih lama dan meningkatkan hasil belajar mereka. Pembelajaran kooperatif memiliki bermacam-macam model, di antaranya adalah Think Pair Share (TPS). Model ini dikembangkan oleh Frank Lyman dan kawan-kawan dari universitas Maryland pada tahun 1985. Menurut Ibrahim (2015) TPS memiliki prosedur yang ditetapkan secara eksplisit untuk memberi siswa waktu lebih banyak untuk berpikir, menjawab, dan saling membantu satu sama lain. Sedangkan Allen dan Tanner (dalam Mufahroyin, 2009; Rizkiwati \& Jailani, 2015) mengatakan TPS memungkinkan siswa memanfaatkan sebaik-baiknya waktu tunggu untuk mempertajam logika berfikir dari permasalahan atau pertanyaan yang diberikan guru.

Think Pair Share termasuk pembelajaran kooperatif yang memberi siswa waktu untuk berpikir dalam dan merespon serta saling bantu sama lain. Model ini memperkenalkan ide "waktu berpikir atau waktu tunggu" yang menjadi faktor kuat dalam meningkatkan kemampuan sisa dalam merespon pertanyaan. Pembelajaran ini melatih siswa untuk berani berpendapat dan menghargai pendapat teman. Peserta didik akan melakukan proses bertukar pikiran dengan koleganya, sehingga pembelajaran ini akan menekan pada proses berfikir peserta didik (Shoimin, 2014). Pembelajaran ini merupakan pembelajaran sederhana yang mempunyai keuntungan dapat mengoptimalkan partisipasi siswa mengeluarkan pendapat, dan meningkatkan pengetahuan. Siswa meningkatkan daya pikir (think) lebih dahulu sebelum masuk ke dalam kelompok berpasangan, kemudian berbagi ke dalam kelompok (share). Setiap siswa diberi ide, pemikiran atau informasi yang mereka ketahui tentang permasalahan yang diberikan.

Nama TPS berasal dari tiga tahap kegiatan siswa yang menekankan pada sesuatu yang dikerjakan siswa pada setiap tahap. Menurut Lyman, dkk (dalam Nurhadi et al., 2004) model TPS mempunyai 3 tahap yaitu Tahap 1-Berfikir (Thinking), 2) Tahap 2-Berpasangan (Pairing), dan 3) Tahap 3-Berbagi (Sharing). Pada tahap Pair, siswa dipasangkan bersama teman disampingnya untuk mendiskusiana jawaban atas pertanyaan tersebut, kemudian bergabung dengan dua orang teman yang ada disampingnya sehingga membentuk 4 orang dalam setiap kelompok untuk bertukar fikiran, ide atau pendapat dari masing-masing individu. Dengan kelompok kecil ini diharapkan siswa lebih aktif belajar untuk menyelesaikan tugas-tugas akademik dan semua anggota kelompok merasa terlibat didalamnya. Pada tahap Share, guru meminta perwakilan kelompok untuk bekerjasama dengan teman sekelasnya dengan cara mempersentasikan hasil diskusinya ke depan kelas. dalam hal ini dapat menumbuhkan rasa percaya diri.

Tahapan penting dalam model pembelajaran TPS terdapat pada tahap Think (berfikir), siswa lebih aktif karena mereka diminta untuk memikirkan jawaban yang diajukan oleh guru secara individu terlebih dahulu sebelum mendiskusikan dengan anggota kelompok ataupun pasangannya. Model ini memberi anak waktu lebih banyak untuk berfikir, menjawab, dan bekerja sama dalam menyelesaikan tugas, sehingga memberdayakan kemampuan berfikir. Hal tersebut sejalan dengan kelebihan TPS menurut Sahrudin (2010) yaitu dapat meningkatkan kemampuan siswa mengingat informasi dan siswa dapat belajar dari siswa lain serta saling menyampaikan idenya untuk didiskusikan sebelum disampaikan di depan kelas.

TPS merupakan suatu cara yang efektif untuk membuat variasi suasa pola diskusi kelas, pembelajaran kelompok siswa diberi kesempatan untuk berfikir mandiri dan saling membantu dengan teman yang lain. Pembelajaran TPS membimbing siswa untuk memiliki tanggung jawab individu dan tanggung jawab kelompok atau pasangannya. Hal ini sejalan dengan pendapat Allen dan Tanner yang mengatakan TPS memungkinkan siswa memanfaatkan sebaik-baiknya waktu tunggu untuk mempertajam logika berfikir dari permasalahan atau pertanyaan yang diberikan guru. Penelitian sebelumnya menunjukkan bahwa pembelajaran kooperatif model TPS membantu siswa meningkatkan: hasil belajar dan memberikan pengaruh lebih baik dibandingan konvensional (Raditya et al., 2015; Handayani \& Yanti, 2017; Muthoharoh, 2017); Memecahkah masalah (Zulfah, 2017); dan Komunikasi matematis (Abdi \& Hasanuddin, 2018; Fahrullisa et al, 2018). 
Kelebihan model TPS (Rosita \& Leonard, 2015) adalah mudah diterapkan pada berbagai tingkat kemampuan berfikir dan kesempatan, siswa diberi waktu lebih banyak berfikir, menjawab dan membantu satu sama lainnya, mengurangi kegaduhan di dalam kelompok dan keaktifan siswa dapat terlihat jelas, lebih mengoptimalkan partisipasi siswa di dalam proses pembelajaran di sekolah. Dalam TPS tahapan diskusi dilakukan oleh kelompok kecil yaitu berpasang-pasang yang meminimalisir adanya siswa yang tidak aktif dan kegaduhan dalam kelompok besar. Selain itu, model TPS juga memungkinkan adanya transfer ilmu secara menyenangkan dan bersifat personal hanya dengan teman pasangannya bertukar ide dalam konteks yang tidak mendebarkan hati sebelum mengemukakan idenya kedalam kelompok yang lebih besar sehingga meminimalisir perasaan takut dan malu bila penyampaian dalam kelompok besar. Pola pembelajaran seperti ini diharapkan dapat merangsang siswa untuk termotivasi dalam pelaksanaan kegiatan pembelajaran sehingga berdampak pada peningkatan hasil belajar.

Keunggulan model TPS adalah mengoptimalkan keaktifan siswa dalam pembelajaran, baik secara individu maupun kelompok, sehingga mereka akan mendapatkan informasi. Selain itu, model ini menghendaki siswa untuk lebih banyak berfikir, menjawab, dan membantu teman dalam kelompok kecil yang heterogen. Hal tersebut dapat membantu mereka lebih mudah dalam mempelajari dan memahami materi pelajaran yang pada akhirnya berpengaruh terhadap hasil belajar meningkat. Interaksi yang terjadi dalam pembelajaran ini juga mampu meningkatkan hasil belajar siswa. Hal ini sesuai dengan hasil penelitian Raditya et al., (2015); Handayani \& Yanti (2017); Muthoharoh (2017); Zulfah (2017); Abdi \& Hasanuddin (2018); dan Fahrullisa et al., (2018) yang menunjukkan pembelajaran kooperatif model TPS dapat membantu siswa meningkatkan hasil belajar dan memberikan pengaruh lebih baik dibandingan ceramah. Berdasarkan uraian tersebut, peneliti mengkaji apakah terdapat pengaruh pembelajaran kooperatif model TPS terhadap hasil belajar siswa kelas X SMA. Tujuan penilitian ini untuk mengetahui pengaruh pembelajaran kooperatif model TPS terhadap hasil belajar siswa kelas $\mathrm{X}$ SMA.

\section{METODE PENELITIAN}

Jenis penelitain ini yaitu eksperimen kuasi dengan desain nonequivalent control group design. Subjek penelitian yaitu siswa kelas X SMA Negeri 3 Sidoarjo. Jumlah subjek penelitian yaitu 70 siswa, kelas XA sebagai kelas kontrol dengan jumlah 35 siswa dan kelas XB sebagai kelas eksperimen dengan jumlah 35 siswa.

Tabel 1. Nonequivalent Control Group Design

\begin{tabular}{cccc}
\hline Kelas & Pretest & Perlakuan & Posttest \\
\hline A & O1 & $\mathrm{X}$ & O2 \\
B & O3 & & O4 \\
\hline
\end{tabular}

Sumber: Analisis Peneliti, 2020

Keterangan:

A $\quad$ Kelas Eksperimen

$\mathrm{B} \quad=$ Kelas Kontrol

O1 = Pretest Kelas Eksperimen

$\mathrm{O} 2=$ Posttest Kelas Eksprimen

$\mathrm{X}=$ Perlakuan Melalui Pembelajaran Kooperatif Model TPS

$\mathrm{O} 3=$ Pretest Kelas Kontrol

O4 = Posttest Kelas Kontrol

Pada penelitian ini, siswa di kelas kontrol dan eksperimen diberikan pretest terlebih dahulu, dan setelah perlakuan kemudian diberikan posttest. Kelas eksperimen diberikan perlakuan pembelajaran kooperatif model TPS sedangkan kelas Kontrol dengan pembelajaran konvensional yaitu ceramah. Instrumen penelitian dengan tes objektif berjumlah 40 butir soal. Masing-masing butir soal pada tes objektif dengan 5 item pilihan jawaban. Instrumen sebelum digunakan diuji kevalidan meliputi analisis tingkat kesukaran, analisis daya beda item tes, validitas, dan reliabilitas. Analisis data menggunakan uji T independent dengan bantuan SPSS 20.00 for Windows. 


\section{TEMUAN DAN PEMBAHASAN}

Data hasil belajar siswa terdiri dari skor rata-rata prates, pascates, dan gain skor. Nilai rata-rata kemampuan awal siswa kelas eksperimen adalah 53,93 dan kelas kontrol 54,00. Nilai modus kelompok kelas ekperimen adalah 60,0 dan 55 untuk kelas kontrol. Nilai median kelas eksperimen dan kontrol sama yaitu 55. Berdasarkan hal teresebut, maka rata-rata skor prates untuk kelas kontrol lebih tinggi dari pada kelas eksperimen. Perbedaan skor rata-rata yang dimiliki oleh kedua kelas tidak terlalu signifikan. Berdasarkan hasil ini, dapat disimpulkan bahwa kemampuan awal kelas kontrol dan kelas eksperimen adalah homogen. Lebih jelasnya dapat dilihat pada tabel 2.

Tabel 2. Distribusi Frekuensi Data Kemampuan Awal Kelas Eksperimen dan Kontrol

\begin{tabular}{ccccccccc}
\hline Kelas & Mean & Median & Mode & Sd & Min & Max & Sum & N \\
\hline Eks & 53,93 & 55,0 & 60,0 & 10,447 & 30 & 70 & 1888 & 35 \\
Kont & 54,00 & 55,0 & 55,0 & 6,703 & 40 & 65 & 1890 & 35 \\
\hline
\end{tabular}

Sumber: Analisis Peneliti, 2020

Kemampuan akhir (pascates) merupakan tes yang diberikan kepada siswa baik kelas eksperimen maupun kontrol sesudah diberi perlakuan atau sesudah materi diberikan. Data kemampuan akhir siswa ini merupakan skor yang diperoleh siswa masing-masing siswa pada pascates. Data ini bertujuan untuk mengetahui besar kemampuan akhir siswa kelas kontrol dan eksperimen, selain itu bertujuan juga mengetahui sebaran sampel berdasarkan atas skor yang diperoleh. Berikut ini diuraikan data tes kemampuan akhir untuk kedua kelompok. Skor rata-rata kemampuan akhir siswa pada kelas eksperimen adalah 80,86 dan kelas kontrol 70,57. Nilai modus kelompok kelas ekperimen adalah 80 dan 75 untuk kelas kontrol. Nilai median kelas eksperimen adalah 80,00 dan sedangkan untuk kelas kontrol adalah 72,50. Data tersebut menunjukkan bahwa rata-rata skor pascates untuk kelas kontrol lebih rendah daripada kelas eksperimen, sehingga dapat dikatakan bahwa kemampuan akhir kelas eksperimen dan kelas kontrol berbeda, untuk lebih jelas dapat dilihat pada tabel 3. Hal ini disebabkan oleh penggunaan model pembelajaran yang berbeda antara dua kelas tersebut. Dari nilai rata-rata yang dimiliki oleh kedua kelas tersebut, baik kelas eksperimen maupun kelas kontrol mengalami peningkatan. Peningkatan nilai rata-rata lebih tinggi dialami oleh kelas eksperimen. Hal tersebut terjadi karena proses belajar mengajar yang dilaksanakan pada kelas.

Tabel 3. Distribusi Frekuensi Data Kemampuan Akhir Kelas Eksperimen dan Kontrol menggunakan tes subjektif

\begin{tabular}{ccccccccc}
\hline Kelas & Mean & Median & Mode & Sd & Min & Max & Sum & N \\
\hline Eks & 80,86 & 80,00 & 80 & 8,595 & 60 & 97,5 & 2830 & 35 \\
Kont & 70,57 & 72,50 & 75 & 6,995 & 60 & 82,5 & 2470 & 35 \\
\hline
\end{tabular}

Sumber: Analisis Peneliti, 2020

Rata-rata gain score kelas eksperimen sebesar 26,57 dan kelas kontrol 16,14. Data tersebut menunjukkan bahwa rata-rata skor hasil belajar geografi kelas eksperimen lebih tinggi daripada kelas kontrol. Dengan demikian, dapat dikemukakan bahwa model TPS berpengaruh terhadap hasil belajar geografi. Hasil gain score lebih jelasnya dapat dilihat pada tabel 4.

Tabel 4. Distribusi Frekuensi Data Gain Score Kelas Eksperimen dan Kontrol

\begin{tabular}{ccccccccc}
\hline Kelas & Mean & Median & Mode & Sd & Min & Max & Sum & N \\
\hline Eks & 26,57 & 25,00 & 25 & 6,862 & 12,5 & 40,0 & 20,00 & 36 \\
Kont & 16,57 & 15,00 & 15 & 4,161 & 10,0 & 25,0 & 16,58 & 38 \\
\hline
\end{tabular}

Sumber: Analisis Peneliti, 2020

Berdasarkan data tersebut dapat disimpulkan bahwa penggunaan model TPS dan diskusi dapat meningkatkan hasil belajar geografi dan penggunaan model TPS memiliki hasil belajar yang lebih tinggi. Dengan demikian, dapat membuktikan bahwa model TPS berpengaruh terhadap peningkatan hasil 
belajar geografi. Hal ini dapat disimpulkan bahwa secara umum hasil belajar geografi siswa dengan pembelajaran kooperatif model TPS lebih baik dari pada siswa dengan pembelajaran diskusi biasa. Perbandingan nilai rata-rata kemampuan awal (prates), kemampuan akhir (pascates) dan hasil belajar (gain score) antara kelas kontrol dan eksperimen divisualisasikan menggunakan grafik pada gambar 1.

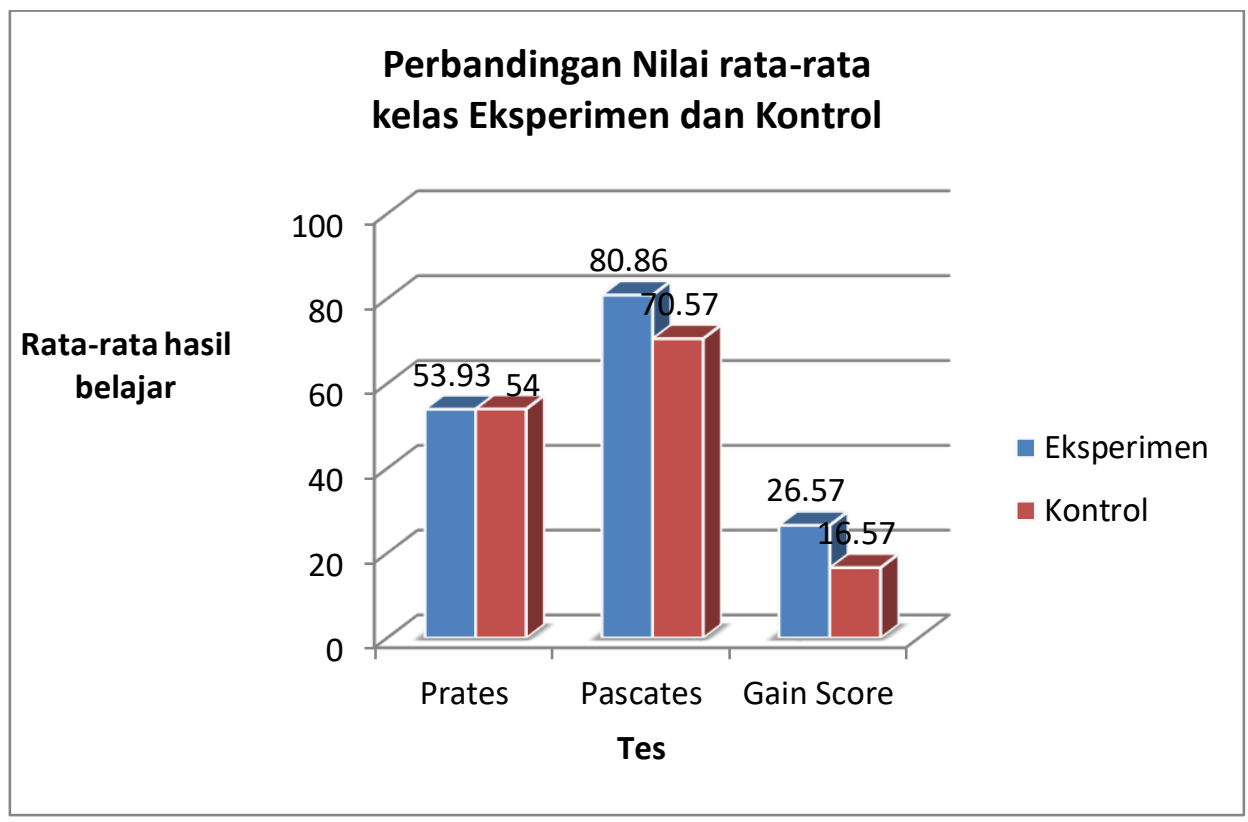

Gambar 1. Grafik Perbandingan Nilai Rata-rata Kelas Eksperimen dan Kontrol (Sumber: Analisis Peneliti, 2020)

Pengujian hipotesis merupakan langkah atau prosedur untuk menentukan apakah hipotesis diterima atau ditolak. Data yang digunakan untuk uji hipotesis adalah data gain score yang diperoleh dari selisih kemampuan akhir (pascates) dan kemampuan awal (prates) kelas eksperimen dan kelas kontrol yang kemudian disebut dengan hasil belajar geografi. Pengujian hipotesis dalam penelitian ini adalah:

Ho : Tidak ada pengaruh pembelajaran kooperatif model TPS terhadap hasil belajar geografi siswa.

Hi : Ada pengaruh pembelajaran kooperatif model TPS terhadap hasil belajar geografi siswa.

Dasar pengambilan keputusan berdasarkan nilai signifikansi sebagai berikut:

Apabila nilai probabilitas (p) $>0,05$ maka Ho diterima

Apabila nilai probabilitas $(\mathrm{p})<0,05$ maka Ho ditolak

Hasil analisis data dengan menggunakan Anova dua jalur dan t-test diketahui nilai sig (2tailed) sebesar 0,000, sehingga $\mathrm{p}<0,05$, dapat diambil keputusan dalam eksperimen ini Ho ditolak dan Hi diterima sebagai hasil penelitian. Hal ini menunjukkan ada pengaruh pembelajaran kooperatif model TPS terhadap hasil belajar geografi, hal ini dikarenakan pada kelas eksperimen diberi pembelajaran kooperatif model TPS sedangkan di kelas kontrol menggunakan pembelajaran diskusi. Data menunjukkan ada perbedaan hasil belajar antara siswa yang belajar dengan menggunakan pembelajaran kooperatif model TPS dengan siswa yang belajar dengan menggunakan pembelajaran diskusi biasa. Di samping itu, dapat disimpulkan bahwa pembelajaran dengan menggunakan pembelajaran kooperatif model TPS lebih baik daripada pembelajaran diskusi. Hasil analisis uji $\mathrm{T}$ independent menggunakan program SPSS16,0 for windows dapat dilihat pada tabel 5.

Tabel 5. Hasil Analisis Uji T Independent

\begin{tabular}{|c|c|c|c|c|c|}
\hline Kelas & df & Sig.(2-tailed) & Mean Dif & Std.Error Dif & Ket \\
\hline Kontrol & \multirow{2}{*}{68} & \multirow{2}{*}{.000} & \multirow{2}{*}{10.4286} & \multirow{2}{*}{1.3613} & \multirow{2}{*}{ Ho ditolak } \\
\hline Eksperimen & & & & & \\
\hline
\end{tabular}

Sumber: Analisis Peneliti, 2020 
Berdasarkan tabel 5 dapat dilihat nilai probabilitas $<0,05$, sehingga Ho ditolak dan Hi diterima. Disimpulkan bahwa terdapat pengaruh pembelajaran kooperatif model TPS terhadap hasil belajar geografi siswa kelas X SMA. Hasil penelitian menunjukkan bahwa model pembelajaran TPS berpengaruh terhadap hasil belajar. Berdasarkan hasil analisis dapat diketahui bahwa terdapat perbedaan hasil belajar siswa yang belajar dengan menggunakan model TPS dengan pembelajaran menggunakan diskusi dan ceramah. Hasil belajar siswa yang belajar dengan menggunakan model TPS lebih tinggi daripada siswa yang belajar dengan pembelajaran diskusi,yakni ditujukkan dengan rata-rata skor tes objektif hasil belajar kedua kelas, kelas ekperimen 26,57 dan kelas kontrol 16,14. Hasil penelitian ini mendukung penelitian sebelumnya yaitu penelitian yang dilakukan oleh Raditya et al., (2015); Handayani \& Yanti (2017); dan Muthoharoh (2017).

Model pembelajaran TPS berpengaruh terhadap hasil belajar siswa di antaranya disebabkan: 1) Melibatkan siswa secara aktif dalam pembelajaran baik pada kegiatan individu dan kelompok, 2) Memberikan kesempatan pada siswa untuk saling membantu dalam mengerjakan tugas yang diberikan oleh guru, 3) Menuntut siswa untuk berusaha sendiri dan bertanggung jawab atas jawaban yang akan dilaporkan kepada kelompoknya, 4) Mengajarkan siswa untuk lebih mandiri dalam mengerjakan soalsoal yang diberikan sehingga dapat meningkatkan rasa percaya diri mereka, 5) Memberi kesempatan kepada siswa untuk memikirkan jawaban dari permasalahan yang diberikan oleh guru sehingga pada saat diskusi kelompok tugas yang diberikan dapat diselesaikan dengan baik. Penggunaan pembelajaran kooperatif model TPS sangat efektif untuk meningkatkan hasil belajar siswa. Salah satu yang berpengaruh terhadap hasil belajar siswa adalah model yang digunakan dalam pembelajaran. Model yang lebih memberikan hasil baik bagi siswa adalah model pembelajaran yang banyak melibatkan siswa berpikir, berargumentasi, berbicara dan mengutarakan gagasan-gagasannya. Sebaliknya hasil yang diperoleh akan rendah apabila siswa hanya pasif dan menjadi pendengar ceramah guru dengan model monolog dari guru (Tu'u, 2014).

Pembelajaran geografi dengan menggunakan pembelajaran kooperatif model TPS lebih meningkatkan keterlibatan siswa secara aktif dalam kegiatan pembelajaran dan meningkatkan pemahaman siswa terhadap materi pelajaran dibanding dengan siswa yang dalam pembelajarannya hanya menggunakan diskusi. Dalam pembelajaran dengan menggunakan model TPS siswa terlibat langsung secara aktif dalam kegiatan individu, kelompok dan presentasi kelompok. Pendekatan struktural TPS mengajarkan siswa untuk lebih mandiri dalam mengerjakan soal-soal yang diberikan sehingga dapat membangkitkan rasa percaya diri siswa, dimana siswa dapat bekerja sama dengan orang lain dalam kelompok kecil. Keunggulan dari pendekatan ini adalah optimalisasi partisipasi siswa, selain itu menghendaki siswa untuk lebih banyak berfikir, menjawab, dan saling membantu dalam kelompok kecil yang heterogen baik secara akademik maupun jenis kelamin.

Selain itu, hal yang menyebabkan model pembelajaran TPS berpengaruh terhadap hasil belajar yaitu tidak lepas dari tahap-tahap pada TPS yang dimulai pada tahap (think), guru memberikan soal dalam bentuk lembar soal, sesuai dengan masalah atau isu yang terkait dengan materi pelajaran. Siswa diberi kesempatan untuk berfikir sendiri mengenai jawaban dari pertanyaan tersebut. Pertanyaan dalam lembar soal dapat menuntun siswa memahami materi yang dipelajari, sehingga pembelajaran menjadi bermakna. Seperti pernyataan Ausabel yang menyatakan bahwa belajar bermakna timbul jika siswa mencoba menghubungkan pengetahuan baru dengan pengetahuan yang dimilikinya.

Tahap berikutnya adalah tahap berpasangan (pair). Pada tahap ini guru meminta siswa untuk berpasangan dengan teman sebangku untuk mendiskusikan mengenai apa yang telah dipikirkan. Interaksi selama periode ini menghasilkan jawaban bersama jika suatu pertanyaan telah diajukan atau penyampaian ide bersama. Proses ini dapat diperpanjang satu proses lebih lanjut yaitu dengan meminta pasangan siswa bergabung dengan pasangan lainnya sehingga membentuk kelompok baru yang terdiri dari empat orang. Mereka menggabungkan ide mereka berempat sebelum membagikan ke kelompok lain yang lebih besar. Tahap pasangan ganda ini juga menggalakkan terjadinya lebih banyak pembicaraan di antara siswa mengenai jawaban dari dipermasalahkan yang ada dalam pertanyaan. Guru dapat membimbing dan mengarahkan siswa. Bersama dengan itu guru dapat menciptakan kondisi yang akrab namun serius, guru mengadakan pendekatan secara personal sehingga siswa tidak takut dan dan lebih termotivasi untuk berpendapat. Hal ini sesuai dengan pendapat Dimyanti dan Mudjiono (2013), bahwa 
intensitas pergaulan guru kepada siswa, dapat mempengaruhi pertumbuhan dan perkembangan jiwa siswa dalam mengikuti kegiatan pembelajaran.

Selanjutnya, pada saat diskusi kelompok siswa menggabungkan ide berempat sebelum membagikan hasil diskusi ke kelompok lain yang lebih besar. Pada langkah ini siswa aktif untuk menjelaskan ide dalam berdiskusi. Langkah ini didukung oleh pendapat Vigosty yang mengatakan bahwa pembelajaran berlangsung ketika siswa bekerja dalam zone of proximal development, sehingga dalam menyelesaikan tugas belajarnya siswa tidak dapat bekerja sendiri. Zone of proximal development merupakan kemampuan siswa dalam menyelesaikan masalah secara individu yang dicapai siswa setelah mendapatkan bantuan dari orang lain yang lebih dewasa atau kompeten (dalam hal ini adalah teman kelompoknya). Kemudian menentukan kesepakatan penyelesaian masalah setelah diskusi dengan teman kelompoknya. Hal tersebut dapat menimbulkan lebih banyak pembicaraan di antara siswa mengenai jawaban dari permasalahan yang ada dalam pertanyaan. Guru dapat membimbing dan mengarahkan siswa. Kemudian guru menciptakan kondisi yang akrab namun serius dengan mengadakan pendekatan secara personal sehingga siswa tidak takut dan dan lebih termotivasi untuk berpendapat. Hal ini sesuai dengan pendapat Dimyanti dan Mudjiono (2013), bahwa intensitas interaksi guru dan siswa, dapat mempengaruhi pertumbuhan dan perkembangan jiwa siswa dalam kegiatan pembelajaran.

Tahap terakhir berbagi (share) dengan persentasi kelompok, guru meminta pasangan-pasangan atau kelompok untuk berbagi atau bekerja sama dengan kelas secara keseluruhan mengenai apa yang telah mereka diskusikan. Pada tahap ini kelompok yang beranggotakan empat orang maju bersama untuk melaporkan hasil diskusinya ke seluruh kelas. Pada langkah ini siswa bertukar fikiran secara menyeluruh, memberikan tanggapan dan memecahkan suatu permasalahan dari pertanyaan yang ada pada lembar soal. Kegiatan presentasi kelompok tersebut bertujuan untuk mengukur penguasaan materi siswa terhadap tugas yang telah diberikan dan melatih keberanian dalam berpendapat dan menjawab pertanyaan. Menurut Piaget (Suparno, 2001) pertukaran gagasan-gagasan tidak dapat dihindari untuk perkembangan penalaran. Para siswa hendaknya diajurkan untuk mempunyai pendapat mereka sendiri (walaupun pendapat mereka itu salah), mengemukakannya, mempertahankannya dan merasa bertanggung jawab atasnya.

Kelebihan model Think Pair Share (TPS) adalah: 1) Memiliki prosedur yang ditetapkan secara ekplisit untuk memberi sisa waktu lebih banyak untuk berfikir, menjawab, dan saling membantu satu sama lain; 2) Memberdayakan kemampuan berfikir siswa; 3) Membiasakan siswa untuk lebih berani mengeluarkan pendapat. Pembelajaran kooperatif model TPS dapat meningkatkan hasil belajar siswa diantaranya disebabkan: 1) TPS memberikan kesempatan pada siswa untuk saling membantu dalam mengerjakan tugas yang diberikan oleh guru, 2) TPS menuntut siswa untuk berusaha sendiri dan bertanggung jawab atas jawabannya dan yang akan dilaporkan kepada kelompoknya, 3) TPS dapat meningkatkan rasa percaya diri siswa, 4) TPS memberi kesempatan kepada siswa untuk memikirkan jawaban dari permasalahan yang diberikan oleh guru sehingga pada saat diskusi kelompok tugas yang diberikan dapat diselesaikan dengan baik, 5) TPS dapat meningkatkan kemampuan siswa dalam mengingat suatu informasi, 6) Siswa menjadi lebih aktif dalam berfikir mengenai konsep dalam mata pelajaran, dan 7) Siswa lebih memahami konsep topik pembelajaran selama diskusi.

Dalam pembelajaran geografi pada materi Hidrosfer dengan menggunakan model TPS ini memungkinkan siswa dapat bekerja sama dengan temannya dimana siswa saling bekerjasama dalam mempelajari materi yang dihadapi. Dalam pembelajaran siswa dilatih untuk mempersentasikan kepada teman sekelas apa yang telah mereka kerjakan. Dari sini siswa memperoleh informasi maupun pengetahuan serta pemahaman yang berasal dari sesama teman dan guru. Dalam penelitian ini hasil belajar menggunakan model pembelajaran TPS hasil belajar lebih baik dibandingkan dengan ceramah dan diskusi. Hasil ini sesuai dengan pendapat Tu'u (2014) bahwa model yang lebih memberikan hasil baik bagi siswa adalah model pembelajaran yang banyak melibatkan siswa berpikir, berargumentasi, berbicara dan mengutarakan gagasan-gagasannya. Sebaliknya hasil yang diperoleh akan rendah apabila siswa hanya pasif dan menjadi pendengar ceramah guru dengan model monolog dari guru

Dalam pembelajaran geografi pada materi Hidrosfer dengan menggunakan model TPS ini siswa dapat bekerja sama dengan temannya, mereka bekerjasama dalam mempelajari materi yang dihadapi. Dalam pembelajaran siswa dilatih mempersentasikan kepada teman sekelas apa yang telah didiskusikan. 
Dari kegiatan tersebut siswa memperoleh informasi maupun pengetahuan serta pemahaman yang berasal dari sesama teman dan guru. Berbeda dengan pembelajaran pada kelas kontrol yaitu diskusi kelompok besar, tidak semua siswa mendapatkan kesempatan untuk berfikir mandiri, sehingga kemampuan berfikir hanya terbatas pada sejumlah siswa saja. Banyak siswa kurang terlibat dalam pembelajaran sehingga motivasi belajar rendah. Motivasi belajar yang rendah berpengaruh terhadap pemahaman siswa dalam menerima materi yang dijelaskan guru. Berdasarkan uraian tersebut dapat diketahui bahwa manfaat model TPS begitu besar dalam pembelajaran. Walaupun demikian, pembelajaran dengan menggunakan model TPS memerlukan pembiasaan.

Model TPS ini masih dirasa asing bagi siswa, karna siswa terbiasa dengan ceramah dan diskusi kelompok besar, sehingga siswa masih harus menyesuaikan dengan model ini. Proses penyesuain memerlukan waktu sehingga secara tidak langsung alokasi waktu kegiatan diskusi tersita untuk proses penyesuaian tersebut akibtnya kegiatan diskusi tidak berjalan dengan maksimal. Jadi, seandainya ada guru yang menerapkan model TPS dalam pembelajaran untuk pertama kalinya dan ternyata hasil yang diperoleh tidak sesuai dengan harapan maka perlu mencoba menerapkannya terus sampai siswa benarbenar terbiasa. Hal ini sesuai dengan yang dikemukakan oleh Whiterington dalam Warih (2017) bahwa kebiasaan belajar siswa bersifat persisten (bertahan terus), seragam dan otomatis. Siswa memang perlu waktu untuk menyesuaikan dengan model pembelajaran ini. Kadang sebagian siswa cepat menyesuaikan dengan pembelajaran ini dan ada juga sebagian siswa lain mungkin menolak suatu usaha untuk mengubah model belajar yang sudah dikenalnya. Untuk itu diperlukan waktu dan kesempatan berlatih sampai siswa benar-benar merasa pas menggunakan sebagai salah satu model pembelajaran.

Pengaruh hasil belajar siswa melalui model TPS pada penilitian ini didukung oleh salah satu penelitian terdahulu yang dilakukan oleh Utomo (2017) yang menyimpulkan bahwa model TPS berpengaruh terhadap hasil belajar geografi. Hasil penelitian menunjukkan bahawa model TPS mampu meningkatkan hasil belajar siswa. Berdasarkan uraian tersebut dapat diketahui bahwa model TPS dapat mempengaruhi hasil belajar. Walaupun demikian, pembelajaran dengan menggunakan model tersebut memerlukan pembiasaan. Model TPS ini masih dirasa asing bagi siswa, karna siswa terbiasa dengan ceramah dan diskusi kelompok besar, sehingga siswa masih harus menyesuaikan dengan model ini. Proses penyesuaian memerlukan waktu sehingga secara tidak langsung alokasi waktu kegiatan diskusi tersita untuk proses penyesuaian tersebut akibtnya kegiatan diskusi tidak berjalan dengan maksimal.

Berdasarkan hasil penelitian yang dilakukan oleh Raditya et al., (2015) bahwa pembelajaran dengan menggunakan pembelajaran kooperatif model TPS berpengaruh terhadap hasil belajar siswa juga. Hal ini dibuktikan dengan adanya peningkatan hasil belajar siswa yang menggunakan model TPS. Sedangakan penelitian yang dilakukan oleh Handayani \& Yanti (2017) menunjukkan bahwa model TPS membantu siswa meningkatkan prestasi belajar, kemampuan berfikir kritis, minat dan kerjasama anggota dalam kelompok jika dibandingkan dengan pembelajaran konvensional dan NHT, TPS memberikan pengaruh yang lebih baik.

Berdasarkan teori dan temuan sebelumnya, dikaitkan dengan penelitian ini hasilnya sangat relevan. Pada penelitian ini model TPS terbukti berpengaruh terhadap hasil belajar geografi yang ditunjukkan dengan hasil belajar geografi siswa. Hal ini menunjukkan TPS lebih baik dibandingkan diskusi. Selama pembelajaran siswa yang mendapat perlakuan berupa TPS terlihat lebih aktif jika dibandingkan dengan kelompok diskusi terlihat kurang aktif. Perbedaan hasil belajar siswa pada kedua kelas dengan perlakuan yang berbeda muncul disebabkan siswa yang diberi pembelajaran TPS mempunyai pengalaman dalam mempersentasikan pendapatnya dan hasil kerjanya pada teman, sehingga siswa tidak akan lupa dengan pelajaran yang baru mereka pelajari. Berdasarkan teori dan temuan sebelumnya, dikaitkan dengan penelitian ini hasilnya sangat relevan. Pada penelitian ini model TPS terbukti berpengaruh terhadap hasil belajar geografi yang ditunjukkan dengan peningkatan hasil belajar geografi siswa. Hal ini menunjukkan TPS lebih baik dibandingkan diskusi.

\section{SIMPULAN}

Hasil analisis statistik menggunakan uji T- independent dengan bantuan SPSS 20.00 menunjukkan signifikan $\mathrm{p}$ value $=0.000<0,05$. Hal ini berarti nilai rata-rata hasil belajar kelas kontrol lebih rendah dibandingkan nilai rata-rata kelas eksperimen. Dengan demikian, maka dapat ditarik kesimpulan dari 
penelitian ini bahwa pembelajaran kooperatif model Think Pair Share (TPS) berpengaruh terhadap hasil belajar geografi. Selain itu, hasil penelitian ini juga menunjukkan bahwa penggunaan model pembelajaran TPS ini lebih baik dibandingkan dengan model pembelajaran konvensional seperti ceramah dan diskusi.

\section{DAFTAR PUSTAKA}

Abdi, M., \& Hasanuddin, H. (2018). Pengaruh Model Pembelajaran Think Pair Share dan Motivasi Belajar terhadap Kemampuan Komunikasi Matematis Siswa Sekolah Menengah Pertama. JURING (Journal for Research in Mathematics Learning), 1(2), 99-110.

Dimyati \& Mudjiono. (2013). Belajar dan Pembelajaran. Jakarta: PT Rineka Cipta.

Fahrullisa, R., Putra, F. G., \& Supriadi, N. (2018). Pengaruh Model Pembelajaran Kooperatif Tipe Think Pair Share (TPS) berbantuan Pendekatan Investigasi terhadap Kemampuan Komunikasi Matematis. NUMERICAL: Jurnal Matematika dan Pendidikan Matematika, 79-86.

Handayani, R. D., \& Yanti, Y. (2017). Pengaruh Model Pembelajaran Kooperatif Tipe Think Pair Share terhadap Hasil Belajar PKn Siswa di Kelas IV MI Terpadu Muhammadiyah Sukarame Bandar Lampung. TER AMPIL: Jurnal Pendidikan dan Pembelajaran Dasar, 4(2), 107-123.

Ibrahim. (2015). Model Pembelajaran Kooperative. Bandung: Remaja Rosda Karya.

Lamba, H. A. (2016). Pengaruh pembelajaran kooperatif model STAD dan gaya kognitif terhadap hasil belajar fisika siswa SMA. Jurnal Ilmu Pendidikan, 13(2).

Muthoharoh, N. B. (2017). Pengaruh Model Pembelajaran Kooperatif" Think Pair Share" terhadap Hasil Belajar Bahasa Inggris. SAP (Susunan Artikel Pendidikan), 2(1).

Nurhadi, Yasin, B., Senduk, A.G. (2004). Pembelajaran Kontekstual dan Penerapannya dalam KBK. Malang: Universitas Negeri Malang.

Raditya, I. W., Kristiantari, M. R., \& Suara, I. M. (2015). Pengaruh Model Pembelajaran Kooperatif Tipe Think Pair Share (TPS) Terhadap Hasil Belajar IPA Siswa Kelas VI SD Gugus Letda Made Putra Kecamatan Denpasar Utara Tahun Ajaran 2014/2015. MIMBAR PGSD Undiksha, 3(1).

Rizkiwati, B.Y. \& Jailani, H. (2015). Efektivitas Model Pembelajaran Problem Based Learning Dipadu Think Pair Share Terhadap Kemampuan Berpikir Kritis dan Hasil Belajar Mahasiswa. Educatio, 10(2), 249-261.

Rosita, I., \& Leonard, L. (2015). Meningkatkan kerja sama siswa melalui pembelajaran kooperatif tipe Think Pair Share. Formatif: Jurnal Ilmiah Pendidikan MIPA, 3(1).

Sahrudin, S. (2010). Model Pembelajaran Think Pair Share. (online). Diakses 26 Juni 2018 dari (http://www.sriudin.com/2010/07/model-pembelajaran-tps.html).

Shoimin, A. (2014). Model Pembelajaran Inovatif Dalam Kurikulum 2013. Yogyakarta: ArRuzz Media.

Slavin, R.E. (2010). Cooperative Learning: Teori, Riset, dan Praktik. Bandung: Nusa Media.

Sulfemi, W. B. (2019). Model pembelajaran kooperatif mind mapping berbantu audio visual dalam meningkatkan minat, motivasi dan hasil belajar IPS. Jurnal PIPSI Jurnal Pendidikan IPS Indonesia), 4(1), 13-19.

Suparno, P. (2001). Teori Perkembangan Kognitif Jean Piaget. Yogyakarta: Kanisius.

Tu’u, T. (2014). Disiplin Pada Perilaku dan Prestasi Siswa. Jakarta: bumi aksara.

Utomo, B. (2017). Perbedaan Hasil Belajar Geografi Antara Siswa Yang Diajar Menggunakan Model Jigsaw Dengan Model Think Pair Share Kelas Xi Di SMA N 2 OKU. Jurnal Dosen Universitas PGRI Palembang.

Warih, S. N. (2017). Hubungan Kedisiplinan Siswa dan Kebiasaan Belajar dengan Hasil Belajar IPS Kelas III SDN Gugus Dewi Kunthi Gunungpati Semarang (doctoral dissertation, universitas negeri semarang). 
Wijaya, H., \& Arismunandar, A. (2018). Pengembangan Model Pembelajaran Kooperatif Tipe STAD Berbasis Media Sosial. Jurnal Jaffray, 16(2), 175-196.

Zulfah, Z. (2017). Pengaruh Penerapan Model Pembelajaran Kooperatif Tipe Think Pair Share Dengan Pendekatan Heuristik Terhadap Kemampuan Pemecahan Masalah Matematis Siswa Mts Negeri Naumbai Kecamatan Kampar. Jurnal Cendekia: Jurnal Pendidikan Matematika, 1(2), 1-12. 